\title{
PERAN PENGETAHUAN KONSUMEN, KETERLIBATAN KONSUMEN, DAN FAKTOR PSIKOLOGIS KONSUMEN PADA INTENSI BERALIH PELANGGAN DEPARTMENT STORE PURWAKARTA KE BELANJA DARING
}

\author{
Oleh : \\ Indra Maulana \\ Program Studi Manajemen - STIE DR. KHEZ Muttaqien Purwakarta \\ Email: indra.maulana1177@gmail.com
}

\begin{tabular}{l}
\hline Article Info \\
\hline Article History: \\
Received 23 July - 2020 \\
Accepted 20 August - 2020 \\
Available Online \\
O7 Sept - 2020
\end{tabular}

\begin{abstract}
In 2017, retail business has decreased. Moreover, these days, conventional retail businesses such as department store isn't only competing with similar businesses. Yet, also compete with businesses that use online shopping methods. The rapid of technological advancement and idea of easy access, encourage consumers to have the intention of switching from conventional shopping to online shopping which is considered effective and efficient. This research was conducted to determine the factors that influence the Customer Switching Intention. In this research, three variables that are expected to influence customer switching intention are Consumer Knowledge $\left(X_{1}\right)$, Consumer Involvement $\left(X_{2}\right)$ and costumer psychological factor $\left(X_{3}\right)$. The Data was collected using accidental sampling technique by spreading questionnaires to 100 respondents who are consumers of department store Purwakarta and also had experience of shopping online. Research data is then analyzed through software SPSS 23. From the results of the research, partially, Consumer Knowledge, Consumer Involvement and costumer psychological factor have positive and significant impact on Customer Switching Intention. And all dependent variables simultaneously affect Customer Switching Intention with the value of $F$ count 45,860 and significance level 0,000 $<0,05$. And the value of $R$ Square shows the results of 0.589 which means that the whole of the dependent variables simultaneously as much as $58.9 \%$.
\end{abstract}

Keyword :

Consumer

Knowledge,

Consumer

Invol/vement,

Costumer

Psyhological

Factor,

Customer

Switching Intention.

\section{PENDAHULUAN}

Seiring dengan pertumbuhan populasi, tingkat konsumsi masyarakat juga semakin tinggi. Banyak produsen dan pemasar yang saling berlomba-lomba untuk memenuhi kebutuhan konsumen. Salah satunya industri ritel. Industri ritel kini tidak hanya bersaing dengan usaha sejenis, namun juga bersaing dengan pelaku bisnis yang menggunakan metode daring (online shopping). Kemajuan teknologi yang semakin pesat mendorong pengetahuan konsumen semakin tanggap terhadap kemudahan akses dalam beberlanja, tingginya minat terhadap kebutuhan variasi, termasuk mulai melibatkan diri secara intens pada pola belanjanya dengan bantuin informasi yang didapat secara daring. Hal tersebut menunjukan bahwa Konsumen juga melakukan mobililasi terhadap pola belanja yang dilakukannya, dari pola konvensional seperti department store mulai beralih pada belanja secara daring, yang didorong oleh intensi peralihan atau biasa dikenal dengan (switching intention). 


\section{KAJIAN PUSTAKA \\ PEGEMBANGAN HIPOTESIS \\ Perilaku Konsumen}

American Marketing Association dalam (Peter dan Olson, 2014) mendefinisikan perilaku konsumen (customer behavior) sebagai sebuah dinamika antara pengaruh dan kesadaran, perilaku dan lingkungan di mana manusia melakukan pertukaran aspek-aspek kehidupan. Artinya, bahwa perilaku konsumen selalu melibatkan perasaan dan pemikiran yang mereka alami serta tindakan yang mereka lakukan dalam proses konsumsi.

\section{Pengetahuan Konsumen}

Mowen dan Engel (dalam Sumarwan, 2011) mendefinisikan pengetahuan konsumen sebagai suatu tingkatan informasi yang dimiliki konsumen mengenai berbagai macam produk dan jasa, serta pengetahuan lainnya yang terkait dengan produk tersebut, dan informasi yang berhubungan dengan fungsinya sebagai konsumen.

\section{Keterlibatan Konsumen}

Keterlibatan konsumen (consumer involvement) merujuk pada sebuah persepsi seorang konsumen mengenai pentingnya dan relevansi pribadinya sebuah objek, peristiwa, atau aktivitas (Hebert E. Krugman dalam Peter \& Olson, 2014). Keterlibatan juga merupakan kondisi motivasi yang memberi energi dan pengarahkan proses kognitif dan afektif konsumen dan perilakunya saat mengambil keputusan (Cohen dalam Peter \& Olson, 2014).

\section{Psikologis Konsumen}

Kotler dan Keller (2009:166) bahwa proses pengambilan keputusan dan keputusan akhir pembelian dihasilkan dari rangsangan pemasaran dan lingkungan yang memasuki kesadaran konsumen, dan sekelompok proses psikologis digabungkan dengan karakteristik konsumen tertentu. Faktor psikologis menjadi bagian dari pengaruh lingkungan di mana seseorang tinggal pada waktu sekarang tanpa mengabaikan pengaruh di masa lalu atau antisipasinya pada waktu yang akan datang.

Menurut Kotler dan Keller (2009:178) bahwa faktor-faktor psikologis yang mempengaruhi keputusan pembelian konsumen, diantaranya :
a. Motivasi
b. Persepsi
c. Pembelajaran
d. Memori

\begin{abstract}
Intensi Beralih Pelanggan
Dalam jurnal (Wulandari, 2016) Intensi beralih pelanggan (Consumer switching intention) dikatakan sebagai sebuah kecenderungan perilaku konsumen yang berhubungan dengan proses beralih maupun berpindah dari satu jasa ke penyedia jasa lainnya. Niat beralih erat kaitannya dengan konsep keinginan untuk berperilaku, yang dibangun atas sikap konsumen terhadap objek dan perilaku sebelumnya. Bansal dalam (Wulandari, 2016) juga menjelaskan bahwa sebuah intensi berpindah (Switching Intention) sebagai tingkat kemungkinan atau kepastian bahwa pelanggan akan berpindah dari penyedia jasa saat ini ke penyedia jasa baru.
\end{abstract}

\section{METODE PENELITIAN}

Penelitian ini menggunakan metode kuantitatif dengan pendekatan deskriptif dan asosiatif. Penelitian ini merupakan penelitian yang bertujuan untuk mengetahui pengaruh ataupun juga hubungan anatara dua variabel atau lebih. Dimana sumber data yang digunakan adalah data primer.

\section{HASIL DAN PEMBAHASAN}

Korelasi antara variabel independen dan variabel dependen memiliki nilai signifikansi sebesar $0.000<0.05$ untuk setiap masingmasing variabel $\mathrm{X} 1, \mathrm{X} 2, \mathrm{X} 3$ terhadap $\mathrm{Y}$. Dengan tingkat hubungan korelasi sebesar 0.6700 .6380 .648 yang tergolong positif dan kuat.

\section{Analisis regresi berganda}

Dari hasil analisis regresi berganda, terdapat hasil regresi $Y=\mathbf{0 , 9 5 7}+\mathbf{0 , 7 4 0} X_{1}+\mathbf{0 , 5 1 9 X} X_{2}+$ $\mathbf{0 , 4 3 9 X}_{3}$. Konstanta $\left(\beta_{0}\right)$ memiliki nilai 0,957 menunjukan bahwa jika nilai $\mathrm{X} 1, \mathrm{X} 2$ dan X3 sama dengan nol, maka nilai $\mathrm{Y}$ sebesar 0,957. Dalam kata lain bahwa Intensi Beralih Pelanggan hanya terwujud sejumlah 0,957 tanpa adanya Pengetahuan Konsumen, Keterlibatan Konsumen dan Faktor psikologis konsumen. Koefisien regresi variabel Pengetahuan Konsumen $\mathrm{X}_{1}$ adalah sebesar 0.740 , Pengetahuan konsumen sebesar 0.519, keterlibatan konsumen sebesar 0.439. Dalam hal ini pengaruh dari seluruh variabel independen berbanding lurus dengan variabel dependen. Artinya, semakin meningkat variabel independen semakin meningkat pula variabel dependen.

\section{Koefesien determinasi}

Diperoleh koefisien determinasi atau $\mathrm{R}$ square adalah 0,589 artinya menunjukan bahwa 
pengaruh variabel Pengetahuan Konsumen, Keterlibatan Konsumen dan Faktor psikologis konsumen terhadap Intensi Beralih Pelanggan secara simultan adalah 0,589 atau $58,9 \%$ dan sisanya sebesar $41,1 \%$ dipengaruhi variabel lain.

\section{KESIMPULAN}

a. Dapat disimpulkan bahwa semakin banyak informasi yang dimiliki oleh konsumen dan membentuk suatu pengetahuan, maka munculah informasi yang mendorong kepercayaan konsumen untuk mencoba beralih dari pola belanja konvensional pada pola belanja daring (online).

\section{REFERENSI}

Assauri, Sofjan. 2013. Manajemen Pemasaran. Jakarta: PT. Grafindo Persada.

Ekayanti, Yulia. "E-commerce Industry One Step Ahead: How to get sales lead". Adways.co.id, 5 october 2016.

Gampu, Anggita Novita dkk. 2015. Analisis Motivasi, Persepsi, dan Pengetahuan Terhadap keputusan nasabah memilih PT. Bank Sulutgo cabang utama Manado. Jurnal online EMBA vol. 3 no. 3 ISSN 2302-11. Universitas Sam Ratulangi.

Ghozali, Imam. 2006. Aplikasi Analisis Multivariate Dengan Program SPSS Cetakan keempat. Semarang: Universitas Diponegoro. Jayawijaya, dkk. 2017. Pengaruh Kelompok Acuan (Reference Group), Kebutuhan Mencari Variasi dan Harga terhadap perpindahan merek (Brand Switching) Blackberry ke Android. Jurnal online Administrasi Bisnis vol.44 no. 1. Universitas Brawijaya.

Kotler \& Keller. 2016. A Framework for Marketing Management Global Edition. USA: Pearson education limited.

Miftah, Ardhian. "Susul Ramayana, Matahari dan 7-Eleven, MAP Tutup gerai lotus". Katadata.com, 24 oktober 2017

Peter, J. Paul dan Jerry C. Olson. 2014. Perilaku Konsumen dan Strategi Pemasaran Edisi 9. Jakarta: Salemba Empat.

Rachman, Fadhly Fauzi. "Marak E- commerce, Konsumen Mulai Beralih ke Belanja Online". Detik.com, 05 Mei 2017. b. Dapat ditarik kesimpulan bahwa semakin tinggi konsumen terlibat (high involvement) pada suatu aktivitas yang melibatkan keputusannya dalam berbelanja, maka intensi atau keinginannya untuk mencoba beralih pada bola belanja baru seperti daring juga akan muncul.

c. Dapat disimpulkan bahwa adanya dorongan factor psikologis untuk mencoba produk yang baru mendorong seorang Konsumen untuk mencoba mencari produk yang berbeda pada tempat yang biasanya digunakannya untuk berbelanja, salah satunya beralih pada metode belanja secara daring (online).

Schiffman dan Kanuk. 2004. Perilaku Konsumen Edisi 7. Jakarta: PT Indeks.

Sugiyono. 2011. Metode Penelitian Kombinasi (Mixed Methods). Bandung: Penerbit Alfabeta.

Sumarwan, Ujang. 2011. Perilaku Konsumen: Teori dan Penerapannya dalam Pemasaran. Jakarta: PT. Ghalia Indonesia.

Susanto, Yosua Dwi dan Nurul Widyawati. 2016. Pengaruh Variety Seeking, Promosi dan Citra Merek terhadap Keputusan Perpindahan Blackberry ke Smartphone. Jurnal online Ilmu dan Riset Manajemen vol. 5 no. 2 ISSN 2461-0593. STIESIA Surabaya.

Tsaanii, Adiilah Adlan dan Lilis Ardini. 2016. Analisis Persepsi dan Keterlibatan Konsumen terhadap Pengambilan Keputusan Pembelian dalam tranksaksi Ecommerce. Jurnal online Ilmu dan Riset Akuntansi vol. 5 no. 6 ISSN 2460-0585. STIE Surabaya.

Wulandari, Viska. 2016. Pengaruh Switching Cost terhadap Word of Mouth dengan Switching Intention sebagai variabel intervening pada pengguna jasa layanan kurir JNE di Samarinda. Jurnal online Ekonomi Manajemen dan Akuntansi vol. 18 no. 2 ISSN 1411-1713. Universitas Mulawarman. 